\title{
Use of optical aids by visually impaired students: social and cultural factors
}

\author{
Uso de auxílios ópticos por escolares com deficiência visual: \\ fatores socioculturais
}

\author{
Gelse Beatriz Martins Monteiro \\ Edméa Rita Temporini ${ }^{2}$ \\ Keila Monteiro de Carvalho ${ }^{3}$
}

${ }^{1}$ Departamento de Oftalmol/Otorrinolaringologia da Faculdade de Ciências Médicas da Universidade Estadual de Campinas - UNICAMP - Campinas (SP) - Brasil.

${ }^{2}$ Livre-docente em Metodologia Científica, Professora associada da disciplina de Oftalmologia, Universidade de São Paulo - USP - São Paulo (SP) - Brasil e UNICAMP - Campinas (SP) - Brasil.

${ }^{3}$ Professora Doutora do Departamento de Oftalmol/Otorrinolaringologia da Faculdade de Ciências Médicas da UNICAMP - Campinas (SP) - Brasil.

Endereço para correspondência: Gelse Beatriz Martins Monteiro. Rua São Vicente de Paulo, 650 - Apto. 54 São Paulo (SP) CEP 01229-010

E-mail: beatriz@fcm.unicamp.br

Recebido para publicação em 21.06.2005

Versão revisada recebida em 06.12 .2005

Aprovação em 24.01.2006

Artigo baseado na Dissertação de Mestrado intitulada - "Concepções e uso de auxílios ópticos por escolares com deficiência visual", apresentada ao curso de pósgraduação em Ciências Médicas, área de concentração Oftalmologia, da Faculdade de Ciências Médicas da Universidade Estadual de Campinas.

Nota Editorial: Depois de concluída a análise do artigo sob sigilo editorial e com a anuência do Dr. Haroldo Vieira de Moraes Jr. sobre a divulgação de seu nome como revisor, agradecemos sua participação neste processo.

\begin{tabular}{l} 
ABSTRACT \\
\hline Purpose: To identify conceptions, social and cultural factors regarding \\
the use of optical aids by visually impaired students and to present \\
information to health and educational professionals. Methods: Qualitative \\
research using spontaneous theater (interactive theater modality based \\
on improvisation) as research instrument. To analyze data, an adapted \\
form of the collective subject discourse technique - procedures for \\
organization of verbal data-was applied. Scenes, gestures, expressions, \\
silences and behaviors were added to the original proposal. The study \\
population included all visually impaired students from elementary \\
public schools, aged 10 to 14 years who attended a resource room in a \\
São Paulo state city. The students were examined at a university low \\
vision service. Results: Little knowledge about the impairment and \\
difficult adaptation to use of optical aids were identified. The students' \\
behavior showed denial of own problems, discomfort on public use of \\
aids and lack of participation in own health decisions. Conclusion: \\
Analysis through spontaneous theater session allows the professional \\
to gather information which is not possible to acquire in the health \\
assistance atmosphere. Needs, difficulties and barriers the users found \\
before the prescribed treatment were identified.
\end{tabular}

Keywords: Vision, low/rehabilitation; Audiovisual aids; Cultural factors; Psychodrama; Students; Teen health

\section{INTRODUCTION}

The new conceptions on health and sociology consider the importance of social and cultural factors that interfere in securing ophthalmologic rehabilitation treatments by optical aids. Adolescents with a diagnosis of low vision frequently find it difficult to comply with the proposed treatment, sometimes as a result of the social and cultural environment in which they live ${ }^{(1)}$.

Thinking about the philosophical implications of modern science, a new concept on health emerges, which includes individual, social and ecological dimensions ${ }^{(2)}$. Indeed, medicine has searched, beyond the analytical thinking, information on the context in which the subject lives in order the better understand and assist him/her.

Ophthalmologists prescribe conventional glasses for distance, high adds, aspherical lenses, magnifiers, telescopes and associated non-optical resources. However, many times they observe that the prescribed optical aid was not put into practice. This results in the need to know about the 
personal difficulties and the atmosphere in which the adolescent, who needs to use these resources, lives. Knowledge about this reality is required for the planning of therapeutic and rehabilitative actions by the professionals in the field of ophthalmology ${ }^{(3)}$.

Qualitative studies when applied to adolescent populations require a relaxed and pleasant atmosphere which can be provided by psychodramatic techniques. It is believed that using spontaneous theater techniques, also called psychodramatic techniques, it is possible to locate the patients in his/ her social context, to know his/her emotional life and to attempt language and communication forms which allow mutual understanding ${ }^{(4)}$.

Spontaneous theater acts by investigation of the psychosocial context and constitutes a new form of understanding human behavior because it tries to understand through artistic creation ${ }^{(5)}$. As an instrument of qualitative research, it allows a more thorough comprehension of the subject's discourse by free expression of ideas and sentiments, in an atmosphere of theatrical improvisation.

With this aim, the study's objective was to identify conceptions and to verify sociocultural aspects regarding the use of optical aids by visually impaired students and to present information to professionals of the health and educational area interested in visual impairment.

\section{METHODS}

A qualitative study was conducted adopting a methodological instrument derived from scenic arts, the spontaneous theater - improvised, interactive theater modality, construed on the basis of stories told by the participants.

For the analysis of the gathered information, the collective subject discourse analysis technique - a set of procedures for organization of discursive data of verbal nature - was adapted $^{(6)}$. Since it is a psychodramatic technique, not only verbal but also scenic information, which includes gestures, expressions, silences and behaviors, was included.

From the talks or scenes the central ideas $(\mathrm{CI})$, which are the synthesis of the discursive content were selected and the collective subject discourses (CSD) were construed in which the thought of the group appears as it were that of one individual ${ }^{(6)}$.

The studied population ( 7 subjects) was the total of visually impaired students, from the public school system, aged 10 to 14 years, who during the field study received support in the resource room for the visually impaired in the municipality of Santa Bárbara d'Oeste (SP). The subjects were previously examined at the Subnormal Vision Service of a university hospital. Agreement to participate was by free and informed consent signed by the responsible persons. The project was approved by the Ethics in Research Committee of the Faculty of Medical Sciences of the "Universidade Estadual de Campinas, UNICAMP".

Data collection was according to the following procedures:

\section{Recording information}

Six spontaneous theater sessions were conducted in the school surroundings usually used by the study population, that is, the resource room for the visually deficient. In addition to the researcher/scene director, the teacher of the resource room, six low vision students and a blind female student participated. A camera operator recorded information by means of audiovisual resources. The audiovisual record films of conversations and behaviors were transcribed and analyzed, obtaining the central ideas - IC - and the collective subject discourses - CSD.

\section{Warming up}

In the preliminary phase of the session, group integration and concentration on the activity was promoted through conversations, games and group dynamics including specific warming up for text production and dramatization.

\section{Dramatization}

Based on a story, a fact or a scene told by some of the participants, improvised staging was made. The subjects participated as protagonists, cooperators and audience (they could sporadically be part of the scene or give a suggestion) always coordinated by the scene director and researcher.

\section{Sharing}

After dramatization, the protagonist returned to the group context, freeing him/herself from the character and being received by the other participants who made personal reports on experienced stories, sentiments, identifications with the dramatized scene.

\section{Processing}

After the session, on basis of the audiovisual record, relevant information was obtained and the statements were analyzed using the collective subject discourse analysis technique.

\section{RESULTS}

The central ideas - CI - and the collective subject discourses - CSD - rendered the information among which the most relevant is pointed out.

The presented following results are grouped according to the phases of the spontaneous theater sessions, that is: a) warming up phase - when informal conversations occur and group context is considered; b) dramatization phase - when the subjects express themselves by means of imaginary events.

\section{a) Warming up phase}

\section{Causes of visual impairment}

CI 1: "I don't know".

CSD: "I don't remember", "I don't know".

Observation: together with the verbal message there were silences and head shaking indicating lack of knowledge about the causes of low vision or blindness. 
CI 2: "I think it is a type of aniridia".

CSD: "I think it is a type of aniridia, I think my "ball" is somewhat open, of the eye, a bit open".

CI 3: "It is because of the cat's urine".

CSD: "It is because of the cat's urine"; "but when my mother was pregnant there was no animal".

\section{Way of using optical aids}

CI 4: "I read near with a telescope but it blurs".

CSD: "When I bring the dictionary to school, when I read like that with the telescope, near, everything becomes blurred".

CI 5: "The telescope is for far and the magnifier for near".

CSD: "The telescope is for far, I have a telescope for the blackboard and a magnifier for small letters; the doctor taught me to use the telescope; my magnifier is for reading and increases 6 times, it is for reading the dictionary, books, mathematics, history book".

"When I am without glasses, everybody says like that, "put the telescope' and I say like that, that the telescope is for far, then they say 'put the telescope', and I come very near and say: this is not possible, the telescope is for far, but they insist".

\section{Asking to exhibit the optical aid}

CI 6: Inhibition on demonstrating the use of glasses and telescope.

CSD: The adolescent, her head down, puts on her glasses (aspheric lenses) and takes them off very rapidly. The group asks her to put them on again so that they can observe better. She blinks, scratches her eyes and soon takes them off. She shows the telescope, adjusts it, says that she sees the colleague very near. Soon she passes on the telescope to somebody else to try it.

\section{Use of glasses}

CI 7: "I only use them when I go to school because they pester me".

CSD: "That girl there is lazy, she is too lazy to use glasses"; "who does not use glasses has to go to the office of the Director"; "I use glasses every day at school because they pester me"; "I only use them to go to school"; "they are powerful, they give me a headache, I still are not used to them, I only use them to go to school; when I do not use them, I see normally, only the glasses help me more"; "I don't use them because a little leg broke".

\section{Reports on use of optical aids}

CI 8: "One day I was dancing only with my stockings on and I slipped and fell like this..." "I was playing soccer and my friend broke my glasses"; "I was riding a bicycle and hit a girl...I apologized but she ran to tell her mother, I went home and turned the television on..."; ".... boy liked to go to the river, he went swimming instead of going to school".

\section{b) Dramatization phase}

CI 9: Denial of the problems

Description of the scene: The mother takes the drugged daughter to a medical visit, but does not give this information to the physician, on the contrary, she states that she has an "attack" and when the physician asks her clearly if they used drugs, mother and daughter deny it. The mother asks more than once if the problem is anemia, if there is need for hospitalization (but is it necessary to hospitalize her?). The physician prescribes an antidepressant (fluoxetine), but on leaving the office the mother leaves the prescription on a piece of furniture and the two of them go home and then go for a walk in a park.

CI 10: Being ashamed to use optical aid in public.

Description of the scene: In the story, an adolescent goes to the school bathroom, and because of lack of toilet paper she asks a friend to fetch it for her. A colleague hears this and spreads it in the school saying that she has a bellyache. When she returns to the classroom, she tells the teacher that her glasses fell into the toilet and were lost on flushing. She asks to go home. On arriving at home, being afraid to be reprimanded by the parents, she discovers the glasses in her purse and says, laughing, that it was a lie.

\section{DISCUSSION}

On working with adolescents and their social abilities it is required to know how they see themselves and give them ample opportunities to discuss their difficulties and the impact of visual impairment on their lives. Low vision is not frequent and this may lead to their feeling different or clumsy among people with normal vision; they may think, erroneously, that there is a greater homogeneity in the populations as there really exists ${ }^{(7)}$.

The age of adolescence is a stage in life where socialization assumes a fundamental importance. In order to belong to a group, adolescents try to be as similar as possible to the others - regarding clothing, haircut, way of speech, general behavior. They want to be adequate and do not want to be different or special ${ }^{(8)}$.

In the group context, during informal conversations, before dramatizations, the adolescents, by means of stimulating questions, talked about their visual difficulties, indicating little knowledge about their own deficiency, many times expressing themselves using popular sayings or stating forgetfulness (Central Ideas 1, 2 and 3).

Regarding adequate use or non-use of optical aids, it was possible to perceive that they know the correct purpose of the aids, but that their use is made difficult due to the lack of information of people with whom they are related. This result is corroborated by a study performed with teachers of public schools in the same geographical region, who recognize their lack of preparation to deal with the visually impaired stu- 
dent $^{(9)}$. In the cases where there is lack of instructions on the use, discomfort occurs and even discontinuance of optical aid (Central Ideas 4 and 5).

Inhibition on demonstrating the use of special glasses with lenses that interfere in the esthetic appearance may be related to the need for social acceptance (Central Idea 6).

The scene represented by the students where the protagonist loses her glasses because they fell into the toilet expresses the sentiment of discomfort regarding the use of an optical aid in public. The social dynamics, in this staging was represented by a colleague who spread the news of a bellyache and by the protagonist who prefers to go away instead of facing the situation (Central Idea 10). The visually impaired perceive themselves as not accepted or not appreciated when they have uninformed companions who can see or those who are afraid of them or pity them ${ }^{(10)}$.

Regarding the adaptation to technology, when there is a need for two aids to follow the classes that require reading the blackboard and the note book, the use is intermittent and alternate, requiring attention for their handling. The purpose is always reading. Although this is a daily activity and occupies a considerable part of the time during day by day school activities, it is always connected to duty and almost never to domestic and daily activities (Central Ideas 7 and 8).

The relationship physician/patient is a relevant aspect in the comprehension of how the treatment is accomplished. In scenes occurring in the medical office, the behavior of those whose role was the patient was one of submission to a treatment which would be prescribed for them - more than once they brought to the surface the wish to be hospitalized in order to be treated. There were no signs of a wish to assume their own treatment, instead, they denied the problems that took them to the visit (Central Idea 9).

In the scene where the patient leaves the office and discards the prescription leaving it on a piece of furniture on leaving and went for walk in the park instead of providing the proposed treatment, there is a clear rupture of the relationship between the individual and medicine. It may be supposed that this phenomenon is connected with the fact that the patient does not feel subjected to the construction of his/her own health.

There is a passivity, acquiescence regarding deficiency. There are no comments as to make periodical medical visits, to modify the type of aid or the diopter power of glass lenses when they show not to be adequate anymore. The way of speaking, with a low voice, low head, sometimes looking to the sides, allows to suppose that there is discomfort when approaching topics related to the deficiency.

In the dramatic context, that is, during staging, when they expressed themselves more freely because they were dealing with imaginary stories without need to be related to real life, they preferred stories in which there were no explicit references to visual impairment and no good visual acuity would be required for the action to develop. There were no demonstrations of interest in pleasant activities which would need good visual acuity; there were no comments on books, card games, crosswords or puzzles.
In order to socialize, they forgo optical aids which may cause discomfort. Plays of colleagues, esthetic harm because of interference in appearance by the glasses and other uncommon resources are extremely important in this phase of the adolescent's life to be omitted as a function of seeing better.

\section{CONCLUSIONS}

The analyzed data led to the following conclusions:

Regarding visual impairment: insufficient knowledge about the causes of visual impairment, understanding of the purpose of optical aids, lack of information on optical aids on the part of the people to whom the subjects relate difficulty in adaptation to the use of optical aids.

As concerns the sociocultural and emotional aspects: discomfort regarding use of optical aids in public, limitations of the use of optical aid to the school period, by pressure, need of preponderant socialization as related to the need to see well, daily activities dissociated from school activities and without the requirement of good visual acuity, denial of visual impairment and lack of participation in the decisions on treatment for own health.

Analysis and observation of the spontaneous theater session allowed the knowledge about behaviors and attitudes which hardly would be revealed in the atmosphere of health assistance. A more complete apprehension of reality allows effectively directing programs and activities in view of preservation of ocular health. Once the social factors which determine individual and collective management responsible for the failure or success of medical actions for ocular health are identified, the professional is in better conditions to evaluate, besides the technical efficiency of optical aids, acceptance of their use in the social milieu and subsequent effective visual rehabilitation.

\section{RESUMO}

Objetivo: Identificar concepções e verificar aspectos socioculturais a respeito do uso de auxílios ópticos por escolares deficientes visuais e oferecer informações a profissionais das áreas de saúde e educacional. Métodos: Utilizou-se pesquisa qualitativa mediante aplicação da técnica do teatro espontâneo - modalidade de teatro interativo, de improviso, construído a partir de histórias contadas pelos participantes. Para análise das informações colhidas, foi adaptada a técnica de análise do discurso do sujeito coletivo, conjunto de procedimentos de organização de dados discursivos de natureza verbal. Por se tratar de técnica psicodramática foram consideradas não somente as informações verbais, mas também as cênicas, que incluem gestos, expressões, silêncios e comportamentos. A população estudada constituiu-se da totalidade de escolares deficientes visuais, com idades entre 10 e 14 anos completos, inseridos no sistema público de ensino, que rece- 
biam apoio pedagógico em sala de recursos para deficientes visuais da cidade de Santa Bárbara d'Oeste (SP), no período da pesquisa. Os sujeitos foram previamente examinados em Serviço de Visão Subnormal de Hospital Universitário. Resultados: Foram identificados conhecimentos insuficientes sobre a própria deficiência e dificuldade de adaptação ao uso dos auxílios ópticos. Na observação de comportamentos, verificou-se desconforto no uso dos auxílios ópticos em público, negação da deficiência visual e falta de participação nas decisões sobre tratamentos para sua própria saúde. Conclusão: A análise de sessões de teatro espontâneo permitiu identificar necessidades, dificuldades e barreiras encontradas pelos sujeitos na efetivação dos tratamentos a eles prescritos, assim como concepções e comportamentos que dificilmente se revelam no ambiente de assistência à saúde.

Descritores: Baixa visão/reabilitação; Recursos audiovisuais; Fatores culturais; Psicodrama; Estudantes; Saúde do adolescente

\footnotetext{
REFERENCES

1. Carvalho KMM. Recursos para visão subnormal. Arq Bras Oftalmol. 1997;60 (3):317-9.

2. Capra F. O ponto de mutação. São Paulo: Cultrix; 1982.

3. Temporini ER. A pesquisa na ciência oftalmológica - o que investigar? Sinopse Oftalmol. 2002;4(1):15-7.

4. Kaufman A. A ação de transformar: teatro pedagógico. J Bras Psiquiatr. 1993;42 (8):421-3.

5. Aguiar M. Teatro espontâneo e psicodrama. São Paulo: Ágora; 1998.

6. Lefèvre F, Lefèvre AMC, Scandar SAS, Yassumaro S. Representações sociais sobre relações entre vasos de plantas e o vetor da dengue. Rev Saúde Pública. 2004;38(3):405-14.

7. Wolffe KE, Thomas KL, Sacks SZ. Focused on: social skills for teens and young adults with visual impairments - Study Guide. New York: AFB Press, American Foundation for the Blind; 2000.

8. Kef S. Psychosocial adjustment and the meaning of social support for visually impaired adolescents. J Vis Impair Blind. 2002;96(1):22-37.

9. Gasparetto MERF, Temporini ER, Carvalho KM, Kara-José N. O aluno portador de visão subnormal na escola regular: desafio para o professor? Arq Bras Oftalmol. 2001;64(1):45-51.

10. Peavey KO, Leff D. Social Acceptance of adolescent mainstreamed students with visual impairments. J Vis Impair Blind. 2002;96(11):808-9.
}

\section{Jornada Internacional de Glaucome da Assuclação Paranaense de Oftelmologia*}

\section{3 a 14 de Qutubro de 2006 Curitiba - PR}

\section{INFORMAÇÕES}

\section{Tel.: (411) 3232-4031 • E-mail: drfcabibi@mp5.com.br}

\section{*Participaçãa neste evento conta 5 pontos para a revalidaçãa do títula de especialista em oftalmalogia}

